\title{
EPIDEMIOLOGY
}

UDC 579.222.7, 614.446.33

\section{Epidemiological and clinical features of the course of postoperative sternomediastinitis (clinical case)}

\author{
O. V. Mironenko ${ }^{1,2}$, L. A. Soprun ${ }^{2}$, A. A. Tovanova ${ }^{1}$, D. A. Obuchov ${ }^{1}$ \\ ${ }^{1}$ North-Western State Medical University named after I. I. Mechnikov, \\ 41, Kirochnaya ul., St. Petersburg, 191015, Russian Federation \\ ${ }^{2}$ St. Petersburg State University, \\ 7-9, Universitetskaya nab., St. Petersburg, 199034, Russian Federation
}

For citation: Mironenko O. V., Soprun L. A., Tovanova A. A., Obuchov D. A. Epidemiological and clinical features of the course of postoperative sternomediastinitis (clinical case). Vestnik of Saint Petersburg University. Medicine, 2021, vol. 16, issue 1, pp. 56-73. https://doi.org/10.21638/spbu11.2021.107

Health-care-related infections are becoming more relevant today. The difficulty and largely of diagnosis increased impact of adverse effects (postoperative period, increase of bed-days, use of irrational antibacterial therapy, use of excessive methods of disinfection) factors of the hospital environment on the human body, contributing to the development of severe postoperative complications, among them, sternomediastinitis occupies a special place in cardiac surgery. The clinical case we represent clearly demonstrates the atypical flow of sternominetite caused by the hypervirulent strain Klebsiella pneumoniae blaNDM-Type. Generally, sternomediastinitis causes Staphylococcus epidermidis, Staphylococcus haemolyticus. Every week the patient stays in the cardiothoracic ward of the hospital is associated with a $15 \%$ increase in the risk of mediastinitis development. The data indicate the need for continuous epidemiological monitoring of the relevant microorganisms that are potential agents of nosocomial infections. Thus, adequate diagnosis, choice of rational treatment tactics and effective antibacterial therapy significantly improve the prognosis of the current of a given severe disease. Early epidemiological diagnosis will help to reduce the risk of the development and spread of hospital-acquired infections in the post-operative period.

Keywords: Klebsiella pneumoniae blaNDM-Type, nosocomial infection, sternomediastinitis, epidemiological process, carbapenemaza, hypervirulence.

\section{Introduction}

Post-operative sternoma-medicine is a life-threatening complication that occurs in about $0.75-1.4 \%$ of all open-heart surgery [1]. Inflammation of the fiber mediastinum, as an independent disease, is known from antiquity. The Roman doctor Galen (160 B. C.) first described it.

(C) St. Petersburg State University, 2021 
There are indications of the possibility of a pus complication in the mediastinum also in the works of other ancient doctors: Avicenna and Baronio. The term "mediastinite" later introduced medieval Arabic physician from Spain Avenzoir, describing a number of characteristic symptoms. In the Russian medical literature, G. Gum made the first description of "inflammation of the ventral barrier" in his book "The Initial Foundations of Medical Science", published in Petersburg in 1786.

Since then, much research has been devoted to this issue. The works of N.I. Pirokov (1852), I.I. Rapova (1888), V.I. Razumovsky (1902) played a big role in the development of surgical access to the rear and front mediastinum. Prominent Soviet surgeons, such as Y. Y. Janelidze, A. N. Bakulev, A. G. Savinov, B. S. Rozanov, B. V. Petrovsky, A. A. Gerke and others, were engaged in matters of clinic and treatment of the mediastinite. The results of the study of theoretical aspects of the problem and practical achievements in the treatment of pustular mediastinites by the middle of the $20^{\text {th }}$ century were summarized in the doctoral thesis (1952) and in the subsequent monograph of A. J. Ivanov "Abscesses and flagmen's of mediastinitis (mediastinitis)". On the basis of many years of clinical experience, B. V. Petrovsky detailed general and specific problems of mediastinum surgery in the monograph "Mediastina Surgery", published in 1960 [2]. Infectious complications following median sternotomy result in a significant increase in hospital mortality, duration, cost of in-patient treatment, and consequently a sharp decline in the quality of medical care provided [3]. A variety of risk factors such as diabetes mellitus, obesity, chronic obstructive pulmonary disease, osteoporosis, asymmetric sternotomy, loss of chest blood supply after myocardial revascularization, do not allow to radically reduce the frequency of development of post-operative sternomediastinitis even in highly specialized centers [4-6].

Pus mediastinitis is inflammation of the fiber mediastinitis. Primary (post-traumatic, postoperative) [7] are distinguished by the source of infection. According to the localization of the primary source of infection, mediastenitis $[7 ; 8]$ distinguishes primary (in the case of primary infection of the fibre mediastinitis) and secondary (in the case of the spread of the inflammatory process from other anatomical regions). Primary pus mediastenitis is currently most commonly caused by injury $[8 ; 9]$. The widespread use of instrumentation and manipulation has led to $60-80 \%$ of trauma mediastenitis, $20-38 \%$ of such mediastenitis have been caused by foreign body damage, and $0.5-3.2 \%$ have been caused by colto-doStab and gunshot wounds to the chest $[10 ; 11]$. There is currently damage from fibrous fibrous endoscopes, endotracheal tubes, gastrointestinal probe, esophageal buffalo, cardiovasculator [12-14].

The outcome of treatment largely depends on timely diagnosis and appropriate surgical treatment. One important aspect is the timely monitoring of hospital flora, with the identification of relevant pathogenic factors, colonization resistance and subsequent eradication of these strains and properties using an epidemiological method.

The risk factors for infectious complications are a large number of diverse hospital microflora. These factors need to be taken into account and adjusted prior to operational interventions, taking into account the legal requirements and flora of the intensive care and operating rooms. Among other preventive measures, the most important are careful aseptic, atraumatic surgical techniques, maintenance of the blood supply and the mechanical integrity of the belly, prevention of and correction of the instability of the belly.

Sternomediastinitis can be treated according to the following characteristics. In the case of non-nogenic sternomediastinitis and the absence of soft tissue or bone, necrosis 
(Type 1) can be treated with re-opening, draining, sternal stabilization and primary closure $[15 ; 16]$. Virulent infections with tissue necrosis (Type II) are best treated with a second dissection, a few days of open treatment and sanitation, and then secondary closure with viable tissue (usually muscle) flaps. Chronic, shouldering infections (Type III) are usually managed by the treatment and coating of muscle flaps $[15 ; 16]$.

Mediastenitis of odontogenic and tonsillogene origin currently dominate among secondary pus mediastenitis [17]. The cause of the secondary odontogenic pulmonary mediastinitis are inflammatory processes of the periosthyte tissues, osteomyelitis of the lower jaw, development of the phlegm of the chin and wing regions, phlegmon of the bottom of the mouth, The fascial spaces of the neck, which are then spread mainly to the anterior mediastinum. According to literature, the incidence of tonsilogen pus mediastenite has also increased to $1.5-2 \%$. In the development of odontogenic and tonsilogen mediastenite, the leading role is played by non-clostridian anaerobes [18].

Anaerobic necrostricidal infection, which is an etiological factor of mediastinitis, contributes to the lightning current of acute inflammatory process with fiber mediastinal lesions.

Studies have shown that Staphylococcus epidermidis, Staphylococcus haemolyticus, Klebsiella pneumoniae (15\% of cases) are the most common bacteriological study, and Streptococcus, Enterococcus faecalis, Acinetobacter, Candida albicans are less common.

The results indicate a quantitative predominance of odontogenic mediastinites of staphylococcal etiology (gram-positive), but the role of purulent-inflammatory processes associated with Klebsiella pneumoniae is increasing $(15 \%)$. This indicates the increasing role of an optionally anaerobic non-producing microflora of gram negative [10; 11]. Carbapenemresistant enterobacteria are the main causative agents of nosocomial infections according to WHO by early 2020, in particular hypervirulent Klebsiella pneumoniae. In the Russian Federation, as in the rest of the world, Klebsiella pneumoniae are topical hospital pathogens and cause a wide range of pathologies in humans: sepsis, bacteremia, respiratory system infections, gastrointestinal tract infections, Eye, primary abscesses, etc. [19]. They are hypervirulent, capable of causing severe, with a death rate of 3-55\%, illnesses in people with normal immunity $[9 ; 12 ; 19]$.

The purpose of this study was to identify and manage the complexity of the epidemiological investigation into a patient's in-hospital infection with the hypervirulent strain Klebsiella pneumoniae.

\section{Materials and methods}

Retrospective analysis of the medical history. In describing this clinical case, the patient signed all necessary informed voluntary consent. In order to solve the problem, microbiological, biochemical, biophysical, molecular-genetic, biological, bio informational and statistical methods of research were applied.

The prospective method was used to identify the source of infections. The first phase involved a microbiological study of the biomaterials obtained from the patient being treated in a multidisciplinary hospital. The composition of samples of biomaterials is estimated by two methods: real-time polymerase chain reaction (PCR-PB) and metagenome sequence analysis for bacteria, percentage of their representation, alpha and beta diversity. 
Bacteria were cultivated on dense and liquid nutrient media, and stored at $15 \%$ glycerin at temperatures minus $70^{\circ} \mathrm{C}$. The species was identified using VITEK-2 Compact (Biomerieux, France) and MALDI-TOF BioType r (Bruker, Germany). The isolates Klebsiella pneumoniae were determined by PCR.

Preparation of DNA matrix for polymerase chain reaction / cell thermolizations were used as a matrix for conducting PCR. The bacteriological loop of the night bacterial culture was suspended in $0.1 \mathrm{ml}$ of a lysing solution $(0.25 \%$ SDS, $0.05 \mathrm{M} \mathrm{NaOH})$ to a concentration of $108-109 \mathrm{COI} / \mathrm{ml}$ in vials of $1.5 \mathrm{ml}$ capacity of Type Eporpendf. The samples were warmed up at $98-100{ }^{\circ} \mathrm{C} \mathrm{c}$ on a water bath or in a solid thermostat, with $0.9 \mathrm{ml}$ of deionized water added to each tube. The samples were centrifuged at 19,000 g for 2 minutes at a temperature of $4{ }^{\circ} \mathrm{C}$. Supernatant was selected into sterile micro bicycles and used as a matrix of 1-2 $\mu \mathrm{l}$ for the PCR reaction.

The commercial GeneJET Plasmid Miniprep Kit (Thermo Fisher Scientific, Waltham, USA) was used to isolate plasmid DNA from bacteria according to the manufacturer's instructions.

The principle of which is based on alkaline lysis of deposited bacterial centrifuge cells in the presence of SDS, with further neutralization of lysate, removal of debris with SDS by centrifugation, Adsorption of plasmid DNA on the silica-based membrane column and its elution from the column membrane after removal of impurities by double-flushing. Plasmid profiles were visualized with $0.7 \%$ agarose gel electrophoresis.

In accordance with Guidelines 4.2. 1890-04 determined the sensitivity of bacteria to HBP by micro breeding in Mueller-Hinton and disco diffusion using commercial disks in 96-hole tablets for the following antibiotics: cefotaxime, ceftapium, ceftazidime, gentamicin, amikacin, Imipenem, meropenem, trimethoprim-sulphamethoxazole, thihecyclin, polymyxin B, ciprofloxacin, ceftazidim-avibaktam, aztreonam-avibaktam. The Klebsiella pneumoniae (Shon et al., 2013) was used to establish the hypermucosity of Klebsiella pneumoniae.

The PCR method with specific primers was used to determine in the genomes of bacteria of the family Enterobacteriaceae strains of Klebsiella pneumoniae genetic determinants of resistance to $\mathrm{BPO}$, genes associated with virulence and capsule Type s. Carbapenem genes were detected by PCP using AmplySens ${ }^{\oplus}$ MDR KPC/OXA-48-FL sets (blaKPC, blaOXA-48like) and AmplySens ${ }^{\circ}$ MDR MBL-FL (blaVIM, blaIMP, blaNDM) (InterLabService). Production of oligonucleotides and sequencing of DNA sequences using the Singer method.

\section{Results of the study}

A clinical case is cited to demonstrate the above data found in available publications. Patient K. was admitted to the reception area of the Multidisciplinary Hospital for Emergency Medical Care 31.01. was diagnosis Unstable Angina. Ischemic Heart Disease (hereinafter IBS). Acute Coronary Syndrome (hereinafter OCD) without raising the ST segment. Post-infarct cardiosclerosis (acute myocardial infarction (hereinafter OIM) from 2019). Type 2 diabetes mellitus, insulin therapy. Hypertensive disease 3-risk SSSO-4. CVB D2. Chronic erosive gastritis without aggravation, chronic mild iron deficiency anemia.

On February 1, the operative intervention was performed - multiple coronary bypass of the anterior interventricular branch of the left coronary artery, aortocoronary bypass of the posterior descending artery. In parallel circulatory conditions, using myocardi- 
al stabilization systems. The coronary reversal of myocardium was carried out with the use of aortic coronary bypass for ischemic disease and various forms of combined pathology. The pre-operative antibiotic therapy was Cefazolin $2 \mathrm{~g}$ in / in one-fold. Artificial ventilation of the lungs was carried out.

On 3 February, laboratory tests revealed a temporal increase in troponin. Post-operative injuries were without separator. Then the coronary was performed. On the second day after the operation, temporary climbs along the lower wall of the myocardium were identified according to EKG data. In the laboratory, there are high markers of myocardial damage. On the basis of clinical, laboratory and instrumental data, the patient is diagnosed with: IBS, OCR with ST segment rise. Noninvasive ventilation was carried out by two-level positive pressure in BIPAP FiO2 mode $50 \%$.

On February 4, the negative trend continued. Creatinine levels were $428 \mu \mathrm{mol} / \mathrm{l}$, urea $27 \mathrm{mmol} / \mathrm{l}$. Hemodialysis was shown. At the same time, the laboratory increased the inflammatory reaction - leukocytes $17 \times 10^{*} 9 / 1$, C-reactive protein (C-reactive, CRP) $472 \mathrm{mg} / \mathrm{l}$, hemoglobin $103 \mathrm{~g} / \mathrm{l}$.

According to instrumental studies, echocardiography (hereinafter ECHO-KG) and multi-helical computer tomography (hereinafter MST) determined thoracic formation.

The diagnosis was that the heart tamponade was clotted - under question; an emergency surgery was shown and performed - restorative surgery, pericardial cavity rehabilitation, left pleural cavity drainage and anterior mediastinum.

During surgery, massive organized blood clots with a total volume of up to $200 \mathrm{ml}$ were found along the anterior lateral surface of the heart. Clots were removed. Pericardial cavity and left pleural cavity were cleaned. No source of hemorrhage was found during the audit. The drains were placed in the left pleural cavity and in the anterior mediastinum. An epicardia electrode was filed to the right ventricle. The sternum was bruised with metal ligatures and two nitinol brackets. A layer of contusion was then applied.

On 6 February, a moderate serosa-hemorrhagic separator was detected on the dressings. According to the drainage, $50-60 \mathrm{ml}$ of separable was detected in 24 hours. Postoperative laceration to the sternum showed no signs of inflammation. The separator was meagre, serous. Drainage was removed. High-flow dialysis (creatinine level: $400 \mathrm{mmol} / \mathrm{l}$, urea: $32.6 \mathrm{mmol} / \mathrm{l}$ ) continued. Respiration of the IVL in the mode of spontaneous ventilation in the airway was (hereinafter SPN-CPAP) $\mathrm{FiO} 240 \%$.

On 8 February, surface ulcers were found in the cross region -2 , in the urethra region -1 . Antiseptic treatment was performed, a zinc ointment was applied. 12 February: stagnant double-sided polysegmental pneumonia, respiratory failure of grade 1.

On February 21, the vacuum dressing (VAC-dressings) revealed a blood-rich content. A mucous pustule sputum was identified from the tracheolarbhial tree.

On 22 February, a hemorrhagic detachable $100 \mathrm{ml}$ time period of 48 hours was found in the receiving chamber of the vacuum apparatus. Aseptic dressing and wound sanitization were performed, local necrectomy of the left wall of the wound was performed, and drainage was connected to the vacuum apparatus. The wound was treated with antiseptic drugs: octinesept, chlorhexidine, betadine, protozoan, hemostatic sponge and surgical incisive film.

On 27 February, a small number of detachments were identified, and areas of minor necrosis were identified. An aseptic dressing and welding of the wound was performed, the drainage was connected to the vacuum apparatus. The wound was treated with anti- 
septic drugs: octinesept, chlorhexidine, betadine, protozoan, hemostatic sponge and surgical incisive film. A Brandling ointment patch was placed at the bottom of the wound.

On March 2, middle pneumothorax on the right (serosa pleuritic is in question?), small drained hydrothorax on the left.

On March 3, the second surgical treatment of the postoperative sternotoma wound was performed. During an audit of the bottom of the wound, areas of focal necrosis were identified, and no pockets of granulation tissue were identified as being active. At the same time, the diastasis of the flap of the sternum on the breath-out up to 2-3 $\mathrm{mm}$ was noted, and the thorax was not broken. The wound was disinfected using antiseptic solutions: octinesept, $0.01 \%$ Miramistin solution, filled with Offlomelide ointment.

On 15 March, a second surgical treatment of the postoperative sternotomy wound was performed. The flaps of the swordfish process and the lower third of the flaps of the sternum to the right and left were resected, then the right pleural cavity was drained, a vacuum dressing was then applied.

On 18 March, the diagnosis was corrected as follows: stagnant bilateral polysegmental pneumonia DP II in the process of resolution with the outcome in DP 0. The IVL was produced.

On 25 March, he was transferred to a hospital. The blindfolds were dry. The pleural drainage determined a small serose-haemorrhagic separable.

On April 5, there was an increase in creatinine blood to $182.4 \mathrm{mmol} / \mathrm{l}$. The antibacterial therapy has been adjusted: amikacin has been eliminated and meropine substituted.

Aspiration retrograde drainage determined $1,350 \mathrm{ml} /$ day of serosa removed. The wound showed no signs of inflammation. The wound continued to be washed continuously with a permeation solution and $0.9 \% \mathrm{NaCl}$ solution.

On April 8, the diagnosis was given: middle hydro-thorax on the right. The righthand pleural puncture was shown. The condition following the performed pleural puncture on the right. Acute severe post-hemorrhagic anemia. Hemorrhagic shock, level 2. Respiration SpO2 IV 97-40\%.

Computer tomography (hereinafter CT) was diagnosed with a picture of right-hand hydrothorax with signs of compression atelectasis of the lower right. On April 13, SpO2 respiration was $97-98 \%$. A large amount of purulent sputum was cleaned from TBD. On 30 April, there was a bleed from the postoperative (P/O) sternotomy wound. The median drainage was secreted with $100 \mathrm{ml}$ of red blood. The bandage was soaked in blood. Flocculation was found in the upper third of the p/o sternotomy wound (hematoma - under question?). During the examination of the wound, the release of scarlet blood $-30 \mathrm{ml}$ was noted.

The treatment of the post/o sternotomy wound, surgical hemostasis and draining of the mediastinum were performed, a fixed cluster of $350 \mathrm{ml}$ was found in the cavity of the wound - sanitation was performed. A source of hemorrhage was found - the intercostal artery on the right side of the $6^{\text {th }}$ intercostal, which was laced with a monothread of the propone 3.0. The wound was bruised.

On May 5, he was transferred to the intensive care and intensive care unit (hereinafter ICU), and oxygen saturation dropped to $80 \%$. Signs of pulmonary edema were detected. On 9 May, the condition was determined to be satisfactory. The dressings were dry, there was a decrease in levels of urea and creatinine, an increase in the rate of tuber filtration (hereinafter SCF), hemoglobin - $94 \mathrm{~g} / \mathrm{l}$, alaninamino transferase (hereinafter ALT) increased to $44 \mathrm{ED} / \mathrm{L}$. 
On 25 May, during the round up, the bandage was found to be dry and no complaints were made. Then discharged under the supervision of a resident surgeon. Klebsiella pneumoniae blaNDM Type was found in a microbiological study of the wound. At the same time, IncR plasmid was isolated in this strain, encoding resistance to fluoroquinolone: aac (6')-Ib-cr and to $\beta$-lactame antibiotics: blaTEM-1B. Diagnosis of complications of prescription. Acute Grade 1 Killip heart failure (hereinafter OCN). Pericardium tamponade with blood clots. Condition after restorations, pericardium cavity inspection and rescue. The anterior mediastinum of 05.02 was drained. IYb post-operative sternotomy by El. Oakley - J.E. Wrigh classification. Condition after secondary surgical treatment of post-operative sternotomy wound, resection of flaps of swordfish process and lower third of flaps of sternum with medial part Y, YI, YII-rib right and left, draining of right pleural cavity, Application of VAC - dressing on postoperative sternotomy wound from 15.03. Condition after secondary surgical treatment of postoperative sternotomy wound, partial contusion of wound with secondary sutures, VAC overlay. The condition after the LP is to the right of 08.04. Right pneumothorax. Acute severe post-hemorrhagic anemia. Second degree hemorrhagic shock. The condition after thoracoscopy on the right, hemostasis, recovery and drainage of the right pleural cavity from 09.04. Acute pus bronchitis OSN IY on Killip with the outcome into chronic heart failure (hereinafter XXX) II A St. III (NYHA). Polyorgan insufficiency syndrome. Stagnant double-sided polysegmental pneumonia. DP II is in the process of resolution. IVL 01.02-25.02. An analysis of the treatment provided, with prescriptions and diagnostic procedures completed is presented on Table 1.

The following microorganisms have been identified during in-patient microbiological monitoring of the wound: Klebsiella pneumoniae, Pseudomonas aeruginosa, Stenotrophomonas maltophilia, Staphylococcus aureus, Staphylococcus epidermidis. The next step was to determine the sensitivity of selected micro-organisms to the HBS by microbreeding in Mueller-Hinton Broth and by disco-diffusion using commercial discs in 96-hole tablets for the following antibiotics. Thus, Klebsiella pneumoniae, isolated from bronchial lavage on 21.02.2020, was resistant to the following antibacterial drugs: amoxiclave, ceftazidim, ciprofloxacin, cetoxime, gentamicin, aztreonam.

Pseudomonas aeruginosa isolated from the severable wound 23.03.2020, resistant to amoxiclave, trimethoprim-sulphamethoxazole, zefotaksim. While Pseudomonas aeruginosa, isolated from bronchial lavage, is resistant to meropenium and ciprofloxacin. Stenotrophomonas maltophilia 23.03.2020, isolated from bronchial alveolage, is resistant to amoxiclate. Staphylococcus aureus, isolated from the severable wound of 15.03.2020, was resistant to clindamycin and erythromycin. Staphylococcus epidermidis isolated from the severable wound 12.02.20 g. is resistant to amoxyclate, cefoxicin, levofloxacin, and, like the previously identified Staphylococcus aureus, exhibited resistance to clindamycin and erythromycin. Data on antibacterial resistance are presented on Table 2.

\section{Discussion}

This clinical case clearly demonstrated the atypical course of sternominedity caused by the hypervirulent strain Klebsiella pneumoniae blaNDM-Type. Generally, sternomediastinitis causes Staphylococcus epidermidis, Staphylococcus haemolyticus. Each week of hospitalization is associated with a 15 per cent increase in the risk of mediastinitis, 
and patient $\mathrm{K}$. has been hospitalized for about four months, which can be described as an extreme risk factor for the development of an ISS. In describing this clinical case, it is important to note the importance of using microbiological monitoring data and rational antibiotic therapy for epidemiological analysis.

In this particular case, there is a late microbiological diagnosis or a complete absence thereof and, based on this circumstance, inadequate antibiotic therapy. For the timely administration of rational antibacterial therapy, it is necessary to carry out microbiological research on genotyping of strains of nosocomial infection, especially within surgical departments and departments of resuscitation and intensive care. This clinical case highlighted the need to change the standards of equipment of surgical units, to introduce the recommendation system antimicrobial therapy control strategy. The introduction of additional methodologies for electronic monitoring of microorganisms is necessary, with subsequent consideration and possibility of control and timely application of epidemiological methods contributing to the elimination of highly pathogenic and high virulent strains.

Therapeutic algorithm, radical surgical rehabilitation, VAC therapy [20], serving as an air-conditioning and "bridge" Type of treatment with additional myoplastic reconstruction. It is recommended as an effective and reliable treatment for severe sternal infections with good results, no recurrence of infections and justified risk. Thus, VAC therapy is a portable and increasingly cost-effective treatment for post-sternotomy mediastinitis. VAC therapy removes wound exudates, edema and cell detachable and has been shown to increase the rate of granulation and healing of wounds [21;22]. It improves the patient's condition.

Studies also show statistically significant decreases in the incidence of reinfections, especially those occurring in the early post-operative period (with 1 week of observation). VAC therapy should still be seen as a first-line therapy in post-sternotomy mediastinitis and as bridge therapy for reconstruction or primary closure.

The duration of stay in the hospital for more than 7 days correlates with the risk of hospital-to-hospital infection of a post-operative injury following cardiac surgery [22]. Which was also confirmed by our research and specifically by this clinical case.

Rapid diagnosis, choice of rational tactics, timely microbiological diagnosis, and adequate antibiotic therapy in patient management and application of high-tech medical care significantly improve the prognosis of disease, contain the spread of antibiotic resistance of strains and contribute to the prevention of nosocomial infection.

The data obtained show that there is a need for continuous epidemiological monitoring of topical microorganisms in departments of cardiac surgery, including with a view to reducing the risk of developing such a formidable complication as post-sternotomy mediastinitis, resulting in a sharp decline in the quality of the medical service provided.

\section{Conclusion}

The problems of diagnosis and treatment of the severe complications of acute sternomediastinitis caused by topical nosocomial infection agents remain extremely acute at present, due to the high incidence of complications and fatalities, long hospitalization periods, Substantial material costs for comprehensive treatment.

The deficiencies identified in microbiological diagnosis need to be corrected by the introduction of an adequate and timely laboratory microbiological diagnosis system in 
Table 1. Brief description of the course of the disease, the occurrence of complications and the scheme of antibacterial therapy

\begin{tabular}{|c|c|c|}
\hline Date & Diagnosis. Condition & Laboratory indicators \\
\hline 31.01 .2020 & $\begin{array}{l}\text { Unstable angina. Coronary heart disease } \\
\text { (hereinafter referred to as CHD). Acute } \\
\text { coronary syndrome (hereinafter referred to } \\
\text { as ACS) without ST segment elevation. Post- } \\
\text { infarction cardiosclerosis (acute myocardial } \\
\text { infarction (hereinafter AMI) since 2019). } \\
\text { Type } 2 \text { diabetes mellitus, insulin therapy. } \\
\text { Arterial hypertension of the 3rd degree of risk } \\
\text { of CVD-4. CVB DE } 2 \text { art. Chronic erosive } \\
\text { gastritis without exacerbation, chronic iron } \\
\text { deficiency anemia of mild severity }\end{array}$ & \\
\hline 01.02 .2020 & & \\
\hline 03.02 .2020 & & Troponin build-up \\
\hline 04.02 .2020 & $\begin{array}{l}\text { Tamponade of the heart with clots - } \\
\text { Negative dynamics is questionable }\end{array}$ & $\begin{array}{l}\text { Creatinine } 428 \mathrm{mmol} / \mathrm{l} \text {, urea }-27 \mathrm{mmol} / \mathrm{l} \text {. } \\
\text { white blood cells } 17 \times 10^{*} 9 / 1 \\
\text { CRP- } 472 \mathrm{mg} / 1 \text {, hemoglobin } 103 \mathrm{~g} / 1\end{array}$ \\
\hline 05.02 .2020 & $\begin{array}{l}\text { Postoperative sternomediastinitis IYb classifi- } \\
\text { cati El. Oakley - J.E. Wrigh }\end{array}$ & \\
\hline 06.02 .2020 & & Creatinine: $400 \mathrm{mmol} / 1$, urea: $32.6 \mathrm{mmol} / 1$ \\
\hline 08.02 .2020 & & \\
\hline
\end{tabular}




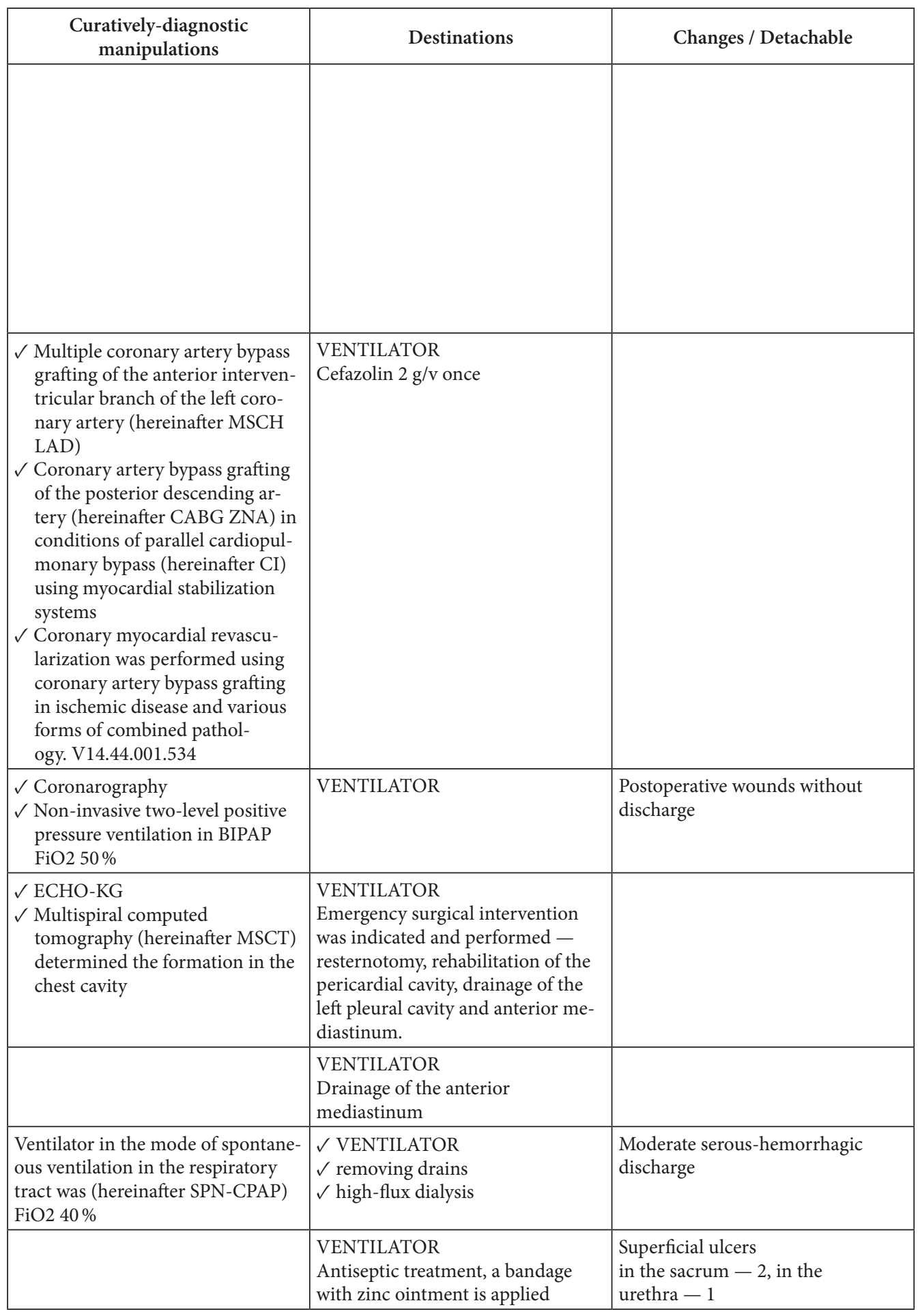




\begin{tabular}{|c|c|c|}
\hline Date & Diagnosis. Condition & Laboratory indicators \\
\hline 12.02.2020 & $\begin{array}{l}\text { Congestive bilateral polysegmental pneumonia } \\
\text { respiratory failure of the 1st degree (hereinafter } \\
\text { DN 1) }\end{array}$ & Staphylococcus epidermidis - sw \\
\hline 21.02 .2020 & & Klebsiella pneumoniae - ba \\
\hline 22.02 .2020 & & \\
\hline 27.02.2020 & & \\
\hline 02.03 .2020 & $\begin{array}{l}\text { Middle pneumothorax on the right (serous } \\
\text { pleurisy questionable?), small enclosed } \\
\text { hydrothorax on the left }\end{array}$ & \\
\hline 03.03.2020 & $\begin{array}{l}\text { Diastasis of the valves of the sternum on } \\
\text { inhalation-exhalation up to } 2-3 \mathrm{~mm}\end{array}$ & \\
\hline 15.03 .2020 & $\begin{array}{l}\text { Condition after secondary surgical } \\
\text { treatment of a postoperative sternotomy } \\
\text { wound, resection of the xiphoid process and } \\
\text { the lower third of the sternal valves with the } \\
\text { medial part of the Y, YI, YII ribs on the right } \\
\text { and left, drainage of the right pleural cavity }\end{array}$ & Staphylococcus aureus - sw \\
\hline 18.03 .2020 & $\begin{array}{l}\text { Congestive bilateral polysegmental pneumonia } \\
\text { DN II in the resolution stage with an outcome } \\
\text { of DN } 0 \text {. } \\
\text { Condition after secondary surgical treatment } \\
\text { of a postoperative sternotomy wound }\end{array}$ & \\
\hline
\end{tabular}


Continuation of the Table 1

\begin{tabular}{|c|c|c|}
\hline $\begin{array}{l}\text { Curatively-diagnostic } \\
\text { manipulations }\end{array}$ & Destinations & Changes / Detachable \\
\hline & VENTILATOR & \\
\hline VAC & VENTILATOR & $\begin{array}{l}\text { VAC-bandages: bloody contents; } \\
\text { TBD: mucopurulent sputum was } \\
\text { determined }\end{array}$ \\
\hline $\begin{array}{l}\text { Local necrectomy of the left wall } \\
\text { of the wound, } \\
\text { drainage was connected to } \\
\text { a vacuum device }\end{array}$ & $\begin{array}{l}\text { VENTILATOR } \\
\checkmark \text { Aseptic dressing and wound } \\
\text { sanitation } \\
\checkmark \text { The wound was treated with } \\
\text { octinesept, chlorhexidine, } \\
\text { betadine, prontosan, } \\
\checkmark \text { covered with a hemostatic } \\
\text { sponge and surgical incision } \\
\text { film }\end{array}$ & $\begin{array}{l}\text { Hemorrhagic discharge in the } \\
\text { volume of } 100 \mathrm{ml}\end{array}$ \\
\hline $\begin{array}{l}\text { The drain was connected to } \\
\text { a vacuum apparatus }\end{array}$ & $\begin{array}{l}\checkmark \text { Aseptic dressing and wound } \\
\text { sanitation } \\
\checkmark \text { The wound was treated with } \\
\text { octinesept, chlorhexidine, } \\
\text { betadine, prontosan, } \\
\checkmark \text { covered with a hemostatic } \\
\text { sponge and surgical incision } \\
\text { film } \\
\checkmark \text { An ointment dressing with } \\
\text { Branolind was placed on the } \\
\text { bottom of the wound }\end{array}$ & $\begin{array}{l}\text { A small amount of discharge, } \\
\text { areas of minor necrosis were } \\
\text { identified }\end{array}$ \\
\hline $\begin{array}{l}\checkmark \text { Secondary surgical treatment } \\
\text { of a postoperative sternotomy } \\
\text { wound } \\
\checkmark \text { Excision of necrotic areas }\end{array}$ & $\begin{array}{l}\checkmark \text { The wound was disinfected using } \\
\text { antiseptic solutions: octinesept, } \\
0.01 \% \text { miramistin solution, } \\
\text { filled with Oflomelid ointment }\end{array}$ & No active discharge was detected \\
\hline $\begin{array}{l}\checkmark \text { Secondary surgical treatment } \\
\text { of a postoperative sternotomy } \\
\text { wound } \\
\checkmark \text { Resections of the xiphoid process } \\
\text { flaps and the lower third of the } \\
\text { sternal flaps on the right and left } \\
\checkmark \text { Drainage of the right pleural } \\
\text { cavity } \\
\checkmark \text { Applying a vacuum dressing }\end{array}$ & & \\
\hline $\begin{array}{l}\text { VENTILATOR } \\
\checkmark \text { Partial suturing of the wound } \\
\text { with secondary sutures } \\
\checkmark \text { Applying a VAC-bandage }\end{array}$ & & \\
\hline
\end{tabular}




\begin{tabular}{|c|c|c|}
\hline Date & Diagnosis. Condition & Laboratory indicators \\
\hline 23.03 .2020 & $\begin{array}{l}\text { Condition after secondary surgical treatment } \\
\text { of a postoperative sternotomy wound }\end{array}$ & $\begin{array}{l}\text { Pseudomonas aeruginosa }-\mathrm{sw} \\
\text { Stenotrophomonas maltophilia }-\mathrm{ba}\end{array}$ \\
\hline 25.03.2020 & Transfer to a hospital & \\
\hline 05.04.2020 & & $\begin{array}{l}\text { Increase in blood creatinine } \\
\text { to } 182.4 \mathrm{mmol} / 1\end{array}$ \\
\hline 08.04 .2020 & $\begin{array}{l}\text { Middle hydrothorax on the right. Condition } \\
\text { after a pleural puncture on the right. Acute } \\
\text { severe posthemorrhagic anemia. Hemorrhagic } \\
\text { shock of the } 2 \text { nd degree }\end{array}$ & $\begin{array}{l}\text { VENTILATOR } \\
\text { SpO2 } 97-40 \%\end{array}$ \\
\hline 09.04.2020 & $\begin{array}{l}\text { Condition after thoracoscopy on the right, he- } \\
\text { mostasis, sanation and drainage of the right } \\
\text { pleural cavity from } 09.04 \text { acute purulent bron- } \\
\text { chitis OSN IY according to Killip with an out- } \\
\text { come in chronic heart failure (hereinafter re- } \\
\text { ferred to as CHF) II A art. III (NYHA) }\end{array}$ & \\
\hline 13.04.2020 & & $\begin{array}{l}\text { VENTILATOR } \\
\text { SpO2 } 97-98 \%\end{array}$ \\
\hline 30.04 .2020 & $\begin{array}{l}\text { Bleeding from a postoperative (hereinafter } \\
\text { referred to as } \mathrm{p} / \mathrm{o} \text { ) sternotomy wound }\end{array}$ & \\
\hline 05.05 .2020 & Transfer to the Intensive Care Unit (ICU) & Oxygen saturation up to $80 \%$. \\
\hline 09.05.2020 & Satisfactory & $\begin{array}{l}\checkmark \text { Reduced urea and creatinine levels, } \\
\checkmark \text { Iincreased glomerular filtration rate } \\
\quad \text { (hereinafter referred to as GFR), } \\
\checkmark \text { Hemoglobin-94 g/l, alanine } \\
\text { aminotransferase (hereinafter ALT) } \\
\text { increased to } 44 \mathrm{U} / \mathrm{l}\end{array}$ \\
\hline 25.05 .2020 & Made no complaints & \\
\hline
\end{tabular}




\begin{tabular}{|c|c|c|}
\hline $\begin{array}{l}\text { Curatively-diagnostic } \\
\text { manipulations }\end{array}$ & Destinations & $\begin{array}{l}\text { Changes/ } \\
\text { Detachable }\end{array}$ \\
\hline \multirow[t]{2}{*}{\begin{tabular}{|l|}
$\checkmark$ Blind suturing of the wound \\
with secondary sutures with \\
aspiration-washing drainage \\
$\checkmark$ Redraining of the right pleural \\
cavity \\
$\checkmark$ Lavage of the right pleural cavity \\
\end{tabular}} & & \\
\hline & & $\begin{array}{l}\sqrt{ } \text { The bandages were dry. } \\
\checkmark \text { A small serous-hemorrhagic } \\
\text { discharge was determined by the } \\
\text { pleural drainage. }\end{array}$ \\
\hline $\begin{array}{l}\text { Continuous washing of the wound } \\
\text { with prontosan solution and } 0.9 \% \\
\text { NaCl solution was } \\
\text { continued }\end{array}$ & & $\begin{array}{l}\checkmark \text { Withdrawal of amikacin, } \\
\text { replacement with meropenem } \\
\checkmark \text { Aspiration retrospinal drainage } \\
\text { was used to determine } \\
1350 \mathrm{ml} / \text { day of serous discharge. } \\
\checkmark \text { The wound showed no signs of } \\
\text { inflammation }\end{array}$ \\
\hline $\begin{array}{l}\text { Computed tomography of right- } \\
\text { sided hydrothorax with signs of } \\
\text { compression atelectasis of the lower } \\
\text { lobe on the right }\end{array}$ & & $\begin{array}{l}\text { A pleural puncture on the right side } \\
\text { was shown }\end{array}$ \\
\hline \multirow[t]{2}{*}{$\begin{array}{l}\text { Sanitation and drainage of the right } \\
\text { pleural cavity }\end{array}$} & & \\
\hline & $\begin{array}{l}\text { TBD was performed sanitization of } \\
\text { a large amount of purulent sputum }\end{array}$ & \\
\hline \multirow[t]{3}{*}{$\begin{array}{l}\checkmark \text { Rehabilitation of the sternotomy } \\
\text { wound, } \\
\checkmark \text { Surgical hemostasis, mediastinal } \\
\text { drainage. } \\
\checkmark \text { The source of the bleeding was } \\
\text { found }- \text { the intercostal artery } \\
\text { on the right in the } 6 \text { th intercostal } \\
\text { space. } \\
\checkmark \text { Then this source was stitched } \\
\text { with monofilament propene } \\
3.0 \text { drainage was performed, the } \\
\text { wound was sutured } \\
\end{array}$} & $\begin{array}{l}\text { A fixed clot with a volume of } \\
350 \mathrm{ml} \text { was found in the wound } \\
\text { cavity }\end{array}$ & \\
\hline & & The dressing is dry \\
\hline & & The dressing is dry \\
\hline
\end{tabular}




\begin{tabular}{|c|c|c|c|c|c|c|c|c|c|c|c|c|c|c|}
\hline әроzечоэ!̣о $\Lambda$ & $\infty$ & & & & & & & & & & & & & \\
\hline әроzeuosn & $n$ & & & & & & & & & & & & & \\
\hline ய!̣dəృəว & & & $\infty$ & $\infty$ & & & & & & & & & & \\
\hline p!̣e & & & & & & $\infty$ & n & & & & & & & \\
\hline шәчәdодәW & & $n$ & $\infty$ & $\simeq$ & & & & & & & & & & \\
\hline әи!хеңојәว & & $\simeq$ & $\simeq$ & & & & & & & & & & & \\
\hline p!ןozəu!T & & & & & & $\infty$ & $\infty$ & & & & & & & \\
\hline ч!̣ехоџонәТ & & & & & $\infty$ & $\infty$ & $\simeq$ & & & & & & & \\
\hline u!̣Кйоэиe $\Lambda$ & & & & & $\infty$ & & & & & & & & & \\
\hline 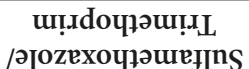 & & & $\simeq$ & & & & & & & & & & & \\
\hline u!̣Кние..qо L & & & $\infty$ & $\infty$ & & & & & & & & & & \\
\hline p!پe & & & & $\infty$ & & & & & & & & & & \\
\hline ч!рехониоо & & & & & $\infty$ & & & & & & & & & \\
\hline นәиәd!̣uI & & $\infty$ & & セ & & & & & & & & & & \\
\hline 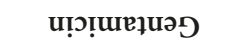 & & $\simeq$ & & & & & & & & & & & & \\
\hline 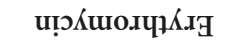 & & & & & & $\simeq$ & $\simeq$ & & & & & & & \\
\hline 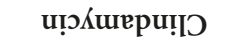 & & & & & & $\simeq$ & $\simeq$ & & & & & & & \\
\hline u!̣рехоџолd!̣ & & $\simeq$ & $\infty$ & $\simeq$ & $\infty$ & & & & & & & & & \\
\hline әи!р!zеңәว & & $\simeq$ & & $\infty$ & & & & & & & & & & \\
\hline บ!ฺ!хојәว & & & & & & $\infty$ & $\simeq$ & & & & & & & \\
\hline ивиоәдұZ & & $\simeq$ & & & & & & & & & & & & \\
\hline u!ा!!ฺ!xouV & & $\simeq$ & $\simeq$ & & & $\infty$ & $\simeq$ & & & & & & & \\
\hline 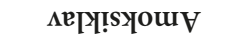 & & is & $n$ & $\infty$ & $\simeq$ & & & & & & & & & \\
\hline 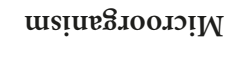 & ث̈ & 苗 & $\mathscr{\tilde { z }}_{\tilde{z}}$ & $\stackrel{\mathscr{E}}{\tilde{z}}$ & 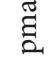 & $\vec{\varpi}$ & Ðे & 总 & 紊 & 党 & 叐 & 肴 & 离 & 总 \\
\hline ә[dures ృo əd $\mathrm{K}_{\mathrm{L}}$ & $\breve{2}$ & $\stackrel{\widetilde{0}}{\Omega}$ & 3 & อี & ڤే & 常 & 总 & 岂 & 旁 & 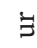 & 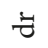 & 岂 & u & 俩 \\
\hline 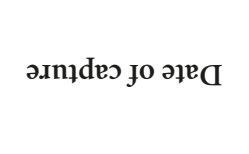 & 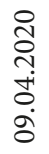 & 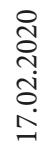 & 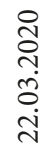 & 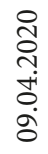 & 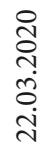 & 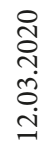 & 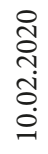 & 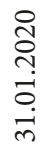 & 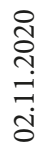 & 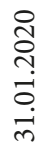 & 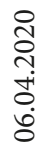 & 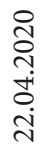 & 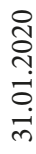 & 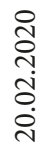 \\
\hline 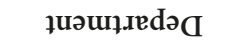 & 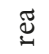 & 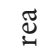 & $\frac{\pi}{\omega}$ & 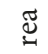 & 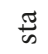 & 苟 & 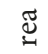 & 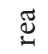 & $\frac{\pi}{\omega}$ & $\stackrel{\Xi}{\mathscr{J}}$ & $\underset{\Xi}{\mathscr{J}}$ & 莹 & $\stackrel{\Xi}{0}$ & ల్ర \\
\hline
\end{tabular}




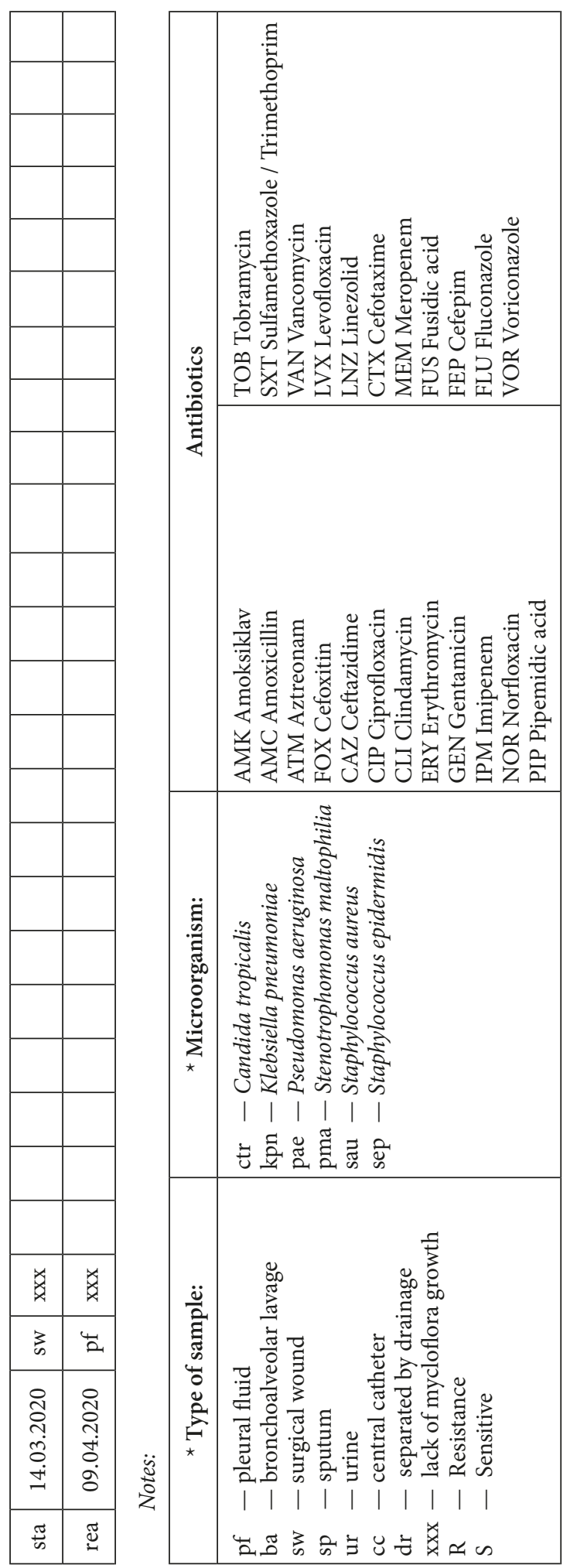


everyday life in Russian medical institutions, Algorithms for prescribing rational antibiotic therapy, recommendation system antimicrobial therapy control strategy, digital technologies with automatic control over the occurrence, development and prevalence of highly pathogenic strains of microorganisms.

\section{References}

1. Robicsek F. Postoperative sterno-mediastinitis. Am. Surg., 2000, vol. 66, no. 2, pp. 184-192.

2. Abacumov M.M. Diagnosis and treatment of purulent mediastinitis is a special chapter in the history of surgery. Khirurgiya. Zhurnal im. N. I. Pirogova, 2019, vol. 3, no. 1. (In Russian)

3. Gostishhev V. K. Infections in thoracic surgery: a guide for doctors. Moscow, OOO Grafikon Publ., 2004. (In Russian)

4. Vogt P. M., Ennker I. C. Practice of plastic surgery: reconstruction of the chest wall. 2011, pp. 164-171.

5. Ennker I. C., Kojcici B., Ennker J., Vogt P., Melichercik J. Examination of opportunity costs and turnover situation in patients with deep sternal infections. Zentralbl. Chir., 2012, no. 137, pp. 184-192.

6. Belov Yu. V., Kosenkov A.N., Vinokurov I. A., Al-Yusef A. Treatment of recurrent traumatic sternomediastinitis after cardiac surgery. Khirurgiya. Zhurnal im. N. I. Pirogova, 2021, no. 2, pp. 53-57. (In Russian)

7. Wingerden J.J. Repeated poststernotomic mediastinitis. UvA-DARE, the institutional repository of the University of Amsterdam. Available at: https://dare.uva.nl (accessed: 20.02.2021).

8. Lednev P. V., Belov Y. V., Stonogin A. V., Lysenko A. V., Salagaev G. I. Postoperative sternomediastinitis. Khirurgiya, 2018, no. 4, pp. 84-89. (In Russian)

9. Yu A. W., Rippel R. A., Smock E., Jarral O. A. In patients with post-sternotomy mediastinitis is vacuum-assisted closure superior to conventional therapy. Interact. Cardiovasc. Thorac. surg., 2013, vol. 17, no. 5, pp. 861-865.

10. Ennker I. C., Ennker J.C. Management of sterno-mediastinitis. HSR Proc. Intensiv. care cardiovask. Anesth., 2012, vol. 4, no. 4, pp. 233-241.

11. Gib M. C., Alvarez J. S., Wender O.C. Mediastinitis: mortality rate comparing single-stage surgical approach and preconditioning of wound. Rev. Bras. Cir. Cardiovasc., 2013, no. 28.

12. Gromov A.L., Gubin M.A., Ivanov S. V., Tishkov D. S. New algorithms of diagnostics of heavy complications of acute odontogenic infection. Rossiiskii stomatologicheskii zhurnal, 2018, vol. 22, no. 2.

13. Kozlov V. A., Egorova O. A. The pecularities of odontogenic mediastinitis diagnostics conditioned by its development mechanism. Vestnik Severo-Zapadnogo gosudarstvennogo medicinskogo universiteta im. I. I. Mechnikova, 2018, vol. 10, no. 4. (In Russian)

14. Gubin M. A., Kharitonov Yu. M., Gromov A. L., Kutishhev A. Yu. Systematics and classification of severe purulent complications in patients with inflammatory diseases of the maxillofacial region and neck. Rossiiskii stomatologicheskii zhurnal, 2010, no. 5. (In Russian)

15. Pechetov A.A., Revishvili A.Sh., Esakov Yu. S., Makov M.A., Volchansky D. A., Khlan T.N. Combined thoracoplasty using titanium mesh implant in patients with total sternal instability following postoperative sternomediastinitis. Khirurgiya. Zhurnal im. N.I. Pirogova, 2019, no. 11, pp. 13-19. (In Russian)

16. Belokonev V.I., Pushkin S. Y. Thoracoabdominal hernia after treatment of chronic sterno-mediastinitis. Khirurgiya, 2019, no. 2, pp. 47-52. (In Russian)

17. European Committee on Antimicrobial Susceptibility Testing. EUCAST guidelines for detection of resistance mechanisms and specific resistances of clinical and/or epidemiological importance, version 1.0, 2012. Available at: https://www.eucast.org/resistance_mechanisms (accessed: 20.02.2021).

18. Ottino G., De Paulis R., Pansini S., Rocca G., Tallone M. V., Comoglio C., Costa P., Orzan F., Morea M. Major sternal wound infection after open-heart surgery: a multivariate analysis of risk factors in 2,579 consecutive operative procedures. Ann. Thorac. Surg., 1987, no. 44, pp. 173-179.

19. Mironenko O. V., Selniceva V.V., Soprun L. A., Shmushkevich E. N., Alekseev A. Yu., Ivanov A. S., Tovanova A. A., Starkova P. S., Naboka V. A. Epidemiological and microbiological characteristics of Klebsiella pneumoniae circulating in St. Petersburg hospital. Problemy medicinskoj mikologii, 2020, vol. 22, no. 3, p. 105. (In Russian)

20. Bain C. J., Lo S., Soldin M. Vacuum-assisted closure should not replace con-ventional therapy in the treatment of sternal wounds. J. Plast. Reconstr. Aesthet. Surg., 2012, no. 65, pp. 833-834. 
21. Leung Wai S. S., Rakesh C., Ahsan A., Samoukovic G., Varennes B., Lachapelle K. Preoperative hospital length of stay as a modifiable risk factor for mediastinitis after cardiac surgery. Journal of Cardiothoracic Surgery, 2013.

22. Conklin C.M., Gray R. J., Neilson D., Wong P., Tomita D.K., Matloff J.M. Determinants of wound infection incidence after isolated coronary artery bypass surgery in patients randomized to receive prophylactic cefuroxime or cefazolin. Ann. Thorac. Surg., 1988, no. 46, pp. 172-177.

Received: February 29, 2021

Accepted: March 25, 2021

Authors' information:

Lidiia A.Soprun - MD, PhD; lidas7@yandex.ru

Olga V.Mironenko - MD, Professor; miroolga@yandex.ru

Anna A. Tovanova - ann.tovan@bk.ru

Denis A.Obuchov - obuhov_2011@bk.ru 